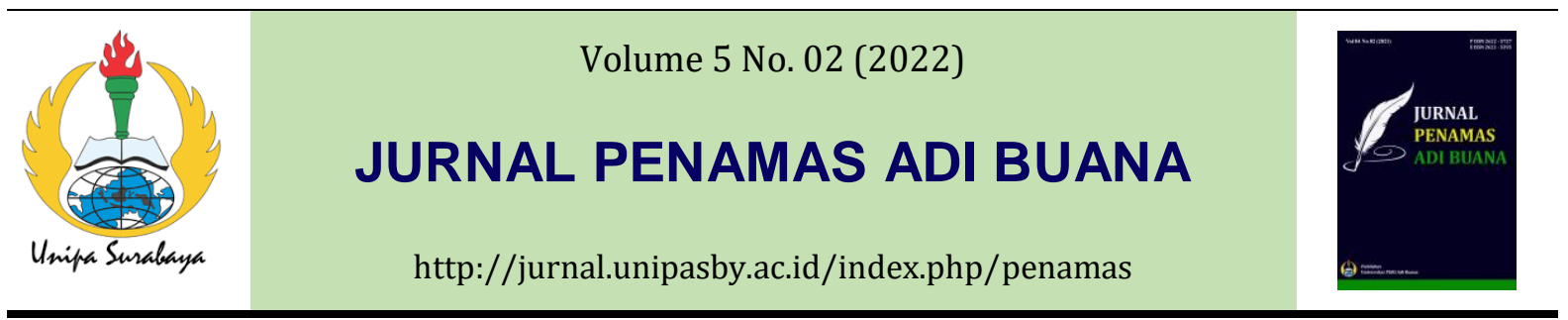

\title{
PELATIHAN PEMBUKUAN DAN PEMASARAN ONLINE UMKM MAKANAN DAN MINUMAN MANGGARSARI KECAMATAN TAMBAKSARI KOTA SURABAYA
}

\author{
Lailatul Amanah $^{1 *}$, Siti Rokhmi Fuadati ${ }^{1}$, Nur Handayani ${ }^{1}$, dan Susanti ${ }^{1}$ \\ ${ }^{1}$ Program Studi Akuntansi, STIESIA Surabaya \\ Email: susanti@stiesia.ac.id
}

\begin{abstract}
Informasi Artikel Abstrak
Kata kunci:

Pembukuan Sederhana,

Laporan Biaya

Produksi, Pemasaran

on-line, Flyer.

Diterima: $15-10-2021$

Disetujui: 05-01-2022

Dipubikasikan: 31-01-

2022

Usaha Mikro Kecil Menengah(UMKM) mempunyai potensi yang masih dapat dikembangkan, baik dalam produktivitas maupun daya saing. Selain itu UMKM juga sangat bermanfaat bagi pelaku usaha karena dapat meningkatkan kemakmuran hidupnya. Dalam prosesnya, ada beberapa UMKM MANGGARSARI yang memproduksi makanan dan minuman di Kecamatan Tambak Sari Kota Surabaya yang dapat berkembang dan kemudian menjadi sukses, namun tak sedikit yang mengalami hambatan. Faktor pendukung dan penghambat yang ada dipengaruhi oleh beberapa faktor diantaranya masalah pemasaran dan teknologi, ketangguhan pelaku usaha, korespondensi, harga dan kualitas produk, kemasan/packaging serta modal. Di bidang pembukuan sederhana tim melakukan pelatihan dalam menyusun laporan keuangan minimal laporan aliran kas dan penyusunan laporan produksi. Di bidang pemasaran tim memberikan pelatihan pemasaran on line dan membuat e-poster sebagai sarana untuk mendukung berjalannya pemasaran online tersebut. Pelaku usaha di UMKM MANGGARSARI diharapkan tetap tangguh dalam menjalani usahanya mengikuti perkembangan jaman serta dapat menyusun laporan keuangan dan menentukan harga jual produknya sesuai dengan biaya. Hal tersebut dapat menjaga memperkuat pelaku usaha UMKM Manggarsari dalam menjalakan kegiatan operasional usahanya.
\end{abstract}

Keywords :

Simple Bookkeeping, Production Cost Reports, On-line Marketing, Flyers

\footnotetext{
Abstract

Micro, Small and Medium Enterprises (MSMEs) have potential that can still be developed, both in terms of productivity and competitiveness. In addition, MSMEs are also very useful for business actors because they can increase their prosperity. In the process, there are several MANGGARSARI MSMEs that produce food and beverages in Tambak Sari District, Surabaya City which can develop and then become successful, but not a few have encountered obstacles.
} 
The supporting and inhibiting factors are influenced by several factors including marketing and technology problems, business actor resilience, correspondence, product price and quality, packaging/packaging and capital. Therefore, in the field of simple bookkeeping, the team conducts training in preparing financial reports, at least cash flow reports and preparing production reports. In the field of marketing, the team provides online marketing training and makes e-posters as a means to support the online marketing. Business actors in MANGGARSARI MSMEs are expected to remain strong in carrying out their business to keep up with the times and be able to compile financial reports and determine the selling price of their products according to cost. This can maintain strengthening the Manggarsari MSME business actors in carrying out their business operations.

\section{PENDAHULUAN}

Usaha Mikro Kecil Menengah (UMKM) merupakan suatu usaha perdagangan yang dikelola oleh perorangan atau badan usaha yang termasuk kriteria usaha dalam lingkup kecil atau mikro. UMKM sebagai usaha kecil dalam kegiatannya dapat membantu perekonomian Indonesia, karena melalui UMKM akan membentuk lapangan kerja baru, memberi kontribusi terhadap pertumbuhan dan peningkatan kesejahteraan serta meningkatkan devisa negara dengan melalui pajak badan usaha. UMKM sebagai usaha mandiri yang dikelola oleh masyarakat dengan menciptakan lapangan pekerjaan diharapkan dapat memberikan kontribusi pada pertumbuhan ekonomi di suatu daerah (Nugroho dkk, 2020).

UMKM mempunyai potensi yang masih dapat dikembangkan, baik dalam produktivitas maupun daya saing. Keberadaan UMKM dapat berfungsi untuk menciptakan teknologi, produk, dan jasa baru yang dapat menciptakan perubahan dan kompetisi pada pasar. Selain itu UMKM juga sangat bermanfaat bagi pelaku usaha karena dapat meningkatkan kemakmuran hidupnya. Dalam prosesnya, ada beberapa UMKM yang dapat berkembang dan kemudian menjadi sukses, namun tak sedikit yang mengalami kegagalan bahkan tak beroperasi. Kesuksesan UMKM dipengaruhi oleh banyak faktor diantaranya adanya pemasaran, teknologi serta modal.

Sari dan Indriyani (2017) menyatakan permasalahan yang sering diabaikan oleh pelaku UMKM salah satunya adalah tentang pengelolaan keuangan, meskipun dampak tersebut tidak terlihat jelas, namun tanpa metode akuntansi yang efektif, para pengelola tidak bisa memahami bisnisnya secara utuh. Selain itu pelaku UMKM juga masih menganggap remeh pembukuan dengan tidak adanya pemisahan antara harta pribadi dengan harta usahanya, sebagian besar pelaku usaha tersebut masih kurang memahami akuntansi dan pelaporan keuangan serta urgensi penggunaanya (Wahyuningsih, 2017) 
Menurut Gunaedi, dkk (2018) kendala utama yang dihadapi UMKM adalah aspek pemasaran dan akses ke lembaga keuangan yang sulit karena masih banyak pelaku UMKM yang belum menyadari pentingnya pencatatan keuangan dan pembukuan yang benar. Dahlan, dkk (2018) juga menemukan kendala yang paling sering dihadapi oleh para pelaku UMKM adalah masalah penyusunan laporan keuangan, karena tidak semua pelaku bisnis usaha mikro memiliki latar belakang pendidikan akuntansi, dan apabila memperkerjakan seorang akuntan masih belum memungkinkan secara finansial. Disamping tidak melakukan pencatatan pembukuan para pelaku UMKM sebagian besar masih mengalami kesulitan dalam menetapkan harga jual yang tepat (Widhiastuti, dkk, 2019). Untuk meningkatan kapasitas pelaku UMKM terutama dalam menghadapi persaingan yang semakin meningkat dibutuhkan pendampingan bagi UMKM (Ardiana, 2010).

Pendampingan juga bertujuan untuk meningkatkan daya saing UMKM agar dapat menguasai pasar, mendapatkan informasi dengan mudah dan cepat, baik informasi mengenai pasar produksi maupun pasar faktor produksi untuk memperluas jaringan pemasaran produk yang dihasilkan oleh UMKM (Sudaryanto, Ragimun, \& Wijayanti, 2014). Hasil penelitian Hadziq dan Nafis (2017) menunjukkan bahwa pemberian pelatihan pelaporan keuangan sederhana memberikan hasil yang sangat signifikan terhadap dampak usaha UMKM. Peningkatan UKMK juga bisa dilakukan dengan memberikan pelatihan dalam bidang manajemen usaha melalui aspek pemasaran, aspek produksi, aspek keuangan serta aspek legalitas usaha dan produk. (Marka, Aziz, \& Alifiana, 2018).

Tujuan dari kegiatan pengabdian kepada masyarakat ini adalah memberikan pelatihan dan pendampingan dalam penyusunan pembukuan sederhana dan pemasaran secara online bagi ibu-ibu pelaku UMKM.

Berdasarkan observasi dilapangan, UMKM Makanan dan Minuman Manggarsari merupakan salah satu UMKM yang memiliki potensi untuk dikembangkan. UMKM ini bergerak di bidang produk makanan dan minuman yang berada di kecamatan Tambaksari Kota Surabaya. UMKM ini terdiri dari sekolompok ibu-ibu rumah tangga yang memproduksi beraneka ragam jenis makanan dan minuman antara lain minuman tradisional, sirup, kue, camilan, dan cathering.

Permasalahan yang dihadapi oleh UMKM Manggarsari selama ini adalah pengelolaan keuangan usaha yang masih tercampur menjadi satu dengan keuangan keluarga. Belum ada upaya untuk memisahkan antara uang untuk kebutuhan rumah tangga dengan kebutuhan usaha. Pengelolaan administrasi keuangan selama ini belum dapat dijalankan secara optimal sehingga berapa pendapatan yang diterima dan pengeluaran usaha belum dapat diidentifikasi dengan jelas. 
Permasalahan lain yang dihadapi adalah masalah pengenalan produk kepada masyarakat. Dimasa sekarang ini untuk meningkatkan penjualan produk penggunaan teknologi akan menjadi solusi terbaik untuk membantu pemasaran produk yang dihasilkan UMKM. Pemasaran melalui media sosial akan memudahkan UMKM untuk menyusun strategi yang sekiranya tepat guna kelangsungan usaha saat ini dan kedepannya. Pembinaan dan pendampingan yang berkesinambungan perlu dilakukan pada UMKM ini agar UMKM ini dapat berkembang dengan baik dan dapat membantu ekonomi keluarga khususnya dan ekonomi masyarakat pada umumnya.

\section{METODE}

Metode pelaksanaan pengabdian dalam masyarakat terdiri dari beberapa hal berikut:

1. Identifikasi Masalah yang dihadapi oleh UMKM Manggarsari

Identifikasi masalah sebagai bagian dari proses upaya untuk mendefinisikan masalah (problem) dan membuat definisi tersebut bisa diukur (measurable) dan dicarikan solusinya. Identifikasi masalah menyediakan platform untuk menyelidiki berbagai intervensi dan menghasilkan opsi. Inisiatif yang dikembangkan dalam langkah-langkah kerangka kerja selanjutnya harus mengatasi masalah yang diidentifikasi di sini. (Hayati, 2019)

Dalam tahapan ini dimulai dengan pembentukan grup WA, anggota grup adalah 9 UMKM dan 4 Dosen STIESIA Surabaya. Lewat grup ini dilakukan identifikasi permasalahan yang dihadapi UMKM terutama dalam masa pandemi Covid-19 ini. Kegiatan ini dilakukan dengan cara percakan lewat chat di grup maupun lewat vidio call.

2. Membantu menyelesaikan masalah yang dihadapi UMKM Manggarsari terkait Pemasaran produk khususnya di masa pandemi covid-19 dengan cara pemasaran digital (E-Poster) Pada tahapan dilakukan dengan:

a. Pemberian materi tentang pemasaran on line secara daring dengan cara mengirimkan materi lewat grup WA dan menjelaskan materi dengan cara melakukan vidio call dengan grup secara bergantian

b. Pembuatan E-Poster

Pada kegiatan ini semua anggota UMKM diminta untuk mengirimkan produkya dan deskripsi produk. Selanjutkan dari foto produk dan deskripsi dibuatkan E-Poster dengan bantuan seluruh mahasiswa yang terlibat dalam kegiatan pendampingan ini, hasilnya dikonsultasikan dengan UMKM kemungkinan ada perubahan dari desain yang sudah dibuat, hal ini dilakukan sampai para UMKM merasa sudah sesuai dengan apa yang diharapkan

3. Membantu menyelesaikan masalah terkait permasalahan pembukuan serta contoh pembukuan transaksi keuangan. Kegiatan ini dilakukan dengan cara: 
a. Memberikan materi pembukuan sederhana bagi UMKM melalui grup WA kemudian dilakukan vidio call dengan anggota grup secara bergantian serta tanya jawab permasalahn pembukuan yang menjadi kesulitan anggota UMKM Manggarsai

b. Memberikan contoh kasus tentang pembukuan transaksi keuangan serta bagaimana cara membukukan transaksi, menghitung harga pokok produk dan menyusun laporan keuangan. Semua kegiatan tersebut dilakukan secara daring.

Pada bagian metode penerapan, uraikanlah dengan jelas dan padat metode yang digunakan untuk mencapai tujuan yang telah dicanangkan dalam kegiatan pengabdian. Hasil pengabdian itu harus dapat diukur dan penulis diminta menjelaskan alat ukur yang dipakai, baik secara deskriptif maupun kualitatif. Jelaskan cara mengukur tingkat ketercapaian keberhasilan kegiatan pengabdian. Tingkat ketercapaian dapat dilihat dari sisi perubahan sikap, sosial budaya, dan ekonomi masyarakat sasaran.

\section{HASIL DAN PEMBAHASAN}

\section{a. Identifikasi Masalah Yang dihadapi oleh UMKM}

Kegiatan ini dilakukan pada bulan April 2020. Dalam tahapan ini dimulai dengan pembentukan grup WA, anggota grup adalah 9 UMKM dan 4 Dosen STIESIA Surabaya. Lewat grup ini dilakukan identifikasi permasalahan yang dihadapi UMKM terutama da masa pandemi Covid-19 ini. Hasil dari identifikasi masalah ini adalah bahwa di masa pandemi Covid-19 ini UMKM merasakan dampak yang berat di awali dengan tingkat penjualan yang turun dengan tajam, dan hal itu sangat dirasakan oleh semua anggota UMKM, sehingga harus ada terobosan bagaimana memasarkan produk yang tepat di masa pandemi ini dengan tetap berada di rumah namun pemasaran tersebut bisa efektif dan menjangkau seluruh elemen masyarakat. Permasalahan lain adalah mereka menemui kesulitan bagaimana harus menghitung harga produk dan mencatat transaksi yang terjadi, sehingga bisa diketahui berapa harga pokok produksi sehingga bisa menetapkan harga jual dengan tepat dengan tingkat keuntungan yang diharapkan, sehingga produk bisa bersaing dengan produsen lainnya. Dengan melalui WA group, UMKM yang telah bergabung pada dasarnya menyambut dengan sangat antusias. Hal tersebut menjadi modal bagi para dosen yang dibantu oleh para mahasiswa untuk semangat dalam melakukan pengabdian masyarakat. Bukti bahwa para UKM menyambut dengan semangat adalah beberapa hasil sceenshoot dibawah ini. Dalam pelaksanaan secara WA ini sudah dapat diperoleh permasalahan, dan telah kami lakukan pemecahannya, banyak UKM yang memimta kembali untuk melakukan pengabdian berikutnya. 

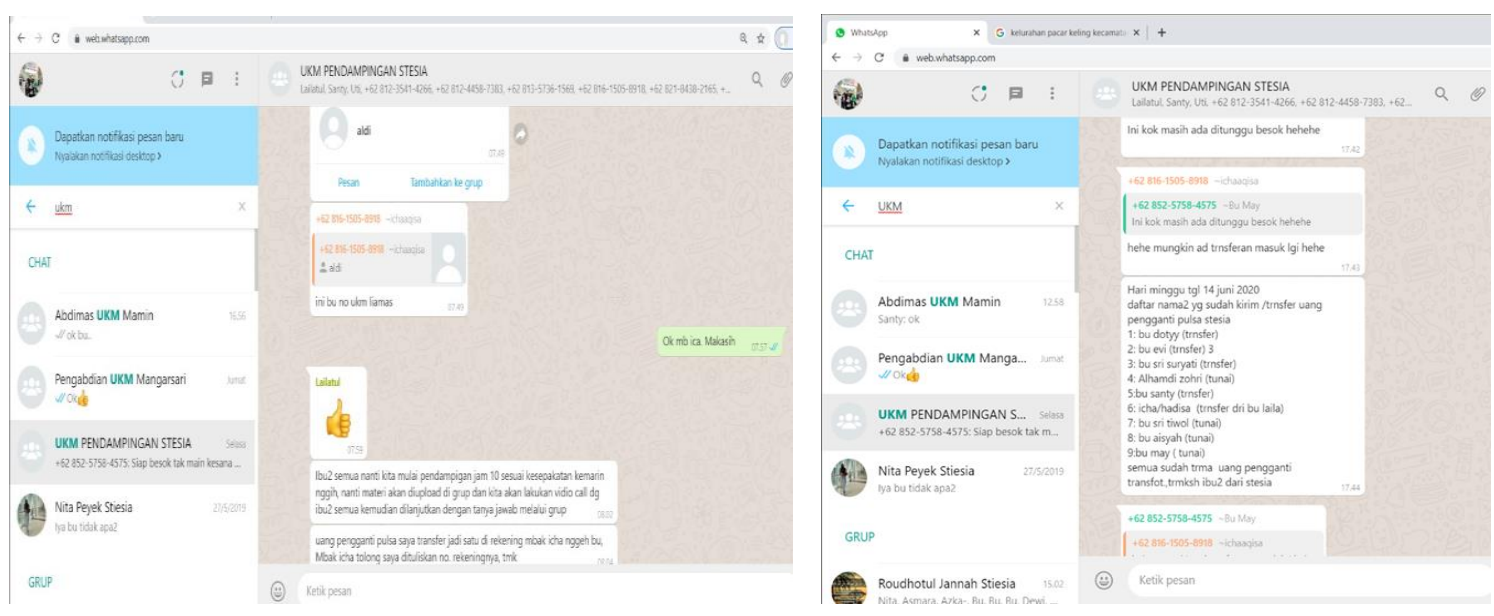

Gambar 1. Diskusi Identifikasi masalah Pemasaran

\section{b. Membantu menyelesaikan masalah yang dihadapi UMKM Manggarsari terkait Pemasaran produk khususnya di masa pandemi covid-19 dengan cara pemberian materi tentang pemasaran online dan pembuatan (E-Poster)}

Kegiatan ini dilakukan mulai bulan Juni 2020. Kegiatan dimulai dengan cara mengupload materi melalui grup WA, dan selanjutnya memberikan penjelasan melalui video call dengan cara mengundang anggota UMKM secara bergiliran, sehingga semua anggota UMKM secara keseluruhan mendapatkan penjelasan materi baik terkait dengan pemasaran online maupun pembukuan transaksi keuangan. Setelah para UMKM mendapatkan penjelasan materi video call selanjutnya mereka dipersilahkan untuk bertanya melalui grup WA, sehingga diskusi yang terjadi antara dosen pendamping dengan anggota UMKM dilakukan melalui grup WA, dan beberapa anggota juga bertanya melalui panggilan WA. Obrolan melalui WA ini sudah dirasa sangat cukup dalam keadaan pandemi ini. Memang banyak kendala di pelaksanaan ini, dikarenakan gangguan siyal dan keterbatasan waktu dan pulsa serta masih banyak UKM yang belum siap dengan sistem aplikasi ini. Dibawah ini kami sertakan materi pemasaran online beberapa screnshoot obrolan di group WA dalam pendampingan kepada UKM.
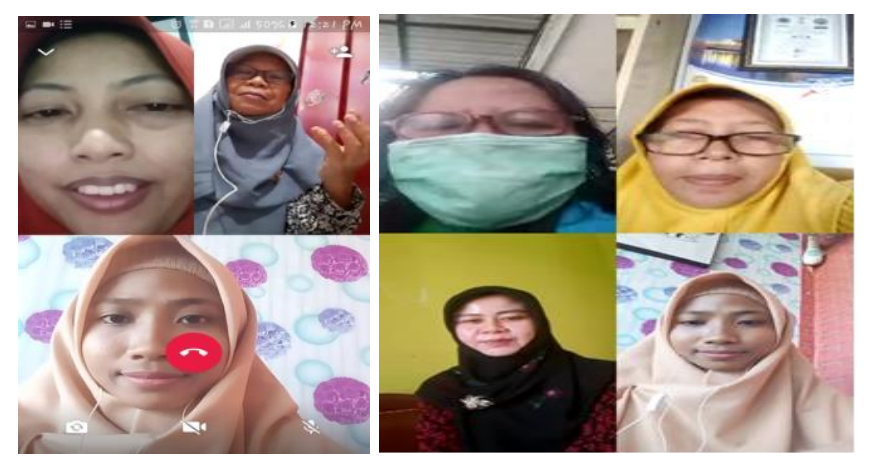

Gambar 2. Penjelasann Materi Pemasaran Online 
Berikut E-Poster produk UMKM yang telah dibuat
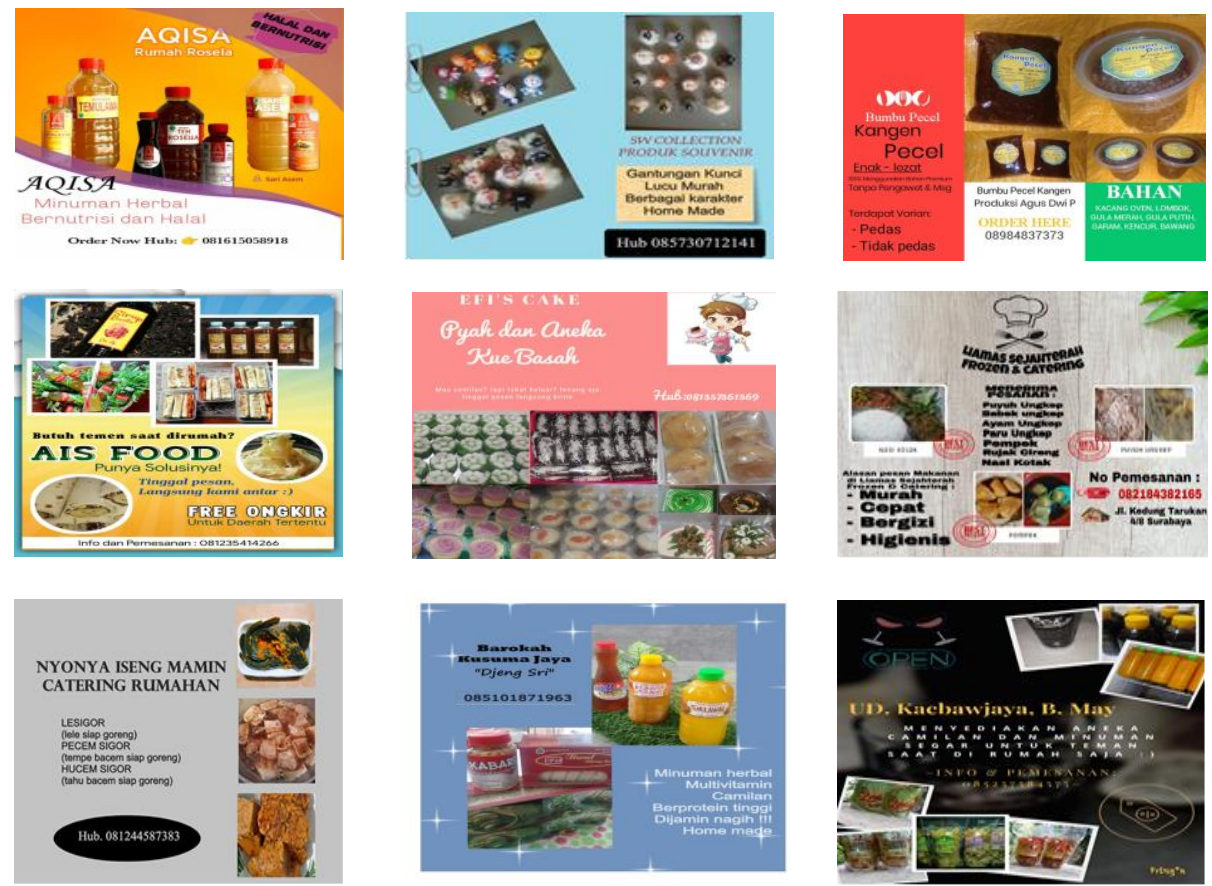

Gambar 3. E-Poster produk-produk UKMK Manggar Sari

c. Membantu menyelesaikan masalah terkait permasalahan pembukuan dengan pemberian materi terkait pembukuan sederhana serta contoh pembukuan transaksi keuangan.
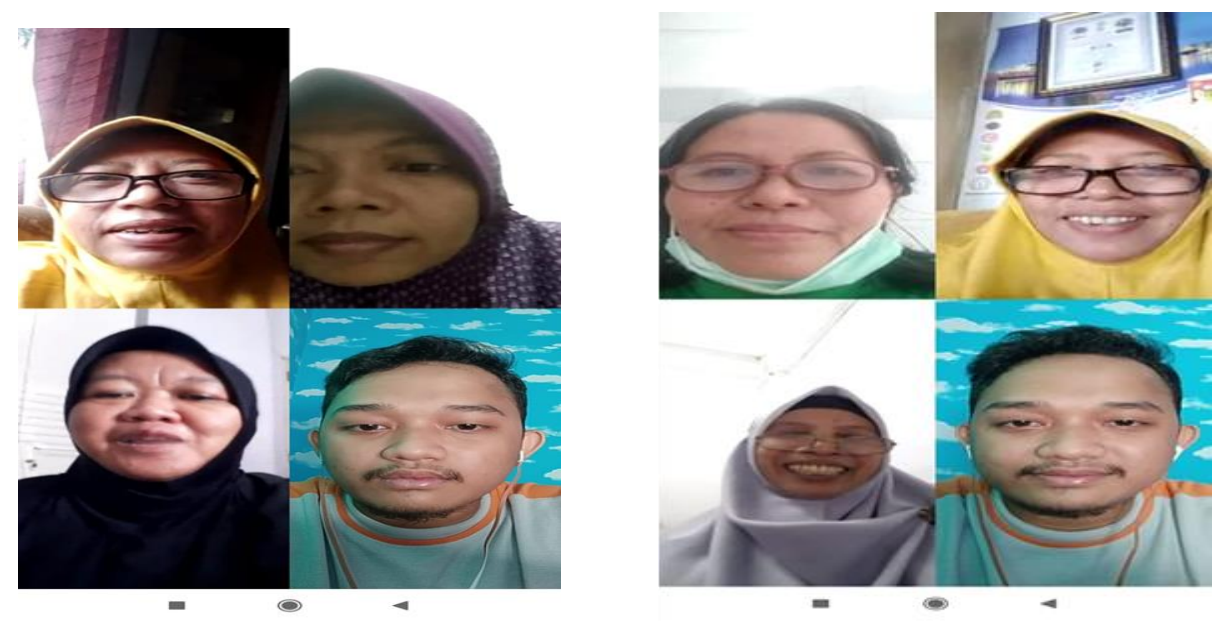

Gambar 4. Pemberian Materi Pembukuan Sederhana

Dalam obrolan lewat WAgrup ini UMKM menanyakan permasalahan yang dihadapi terkait bagaimana membukukan transaksi usahanya serta bagaimana menghitung harga pokok untuk menentukan harga jual produk serta menentukan besaran keuntungan yang diinginkan.

Pengabdian kepada masyarakat adalah usaha untuk menyebarluaskan ilmu pengetahuan, teknologi, dan seni kepada masyarakat. Kegiatan tersebut harus mampu memberikan suatu nilai tambah bagi masyarakat, baik dalam kegiatan ekonomi, kebijakan, dan perubahan perilaku (sosial). 
Uraikan bahwa kegiatan pengabdian telah mampu memberi perubahan bagi individu/masyarakat maupun institusi baik jangka pendek maupun jangka panjang.

Pada bagian ini uraikanlah bagaimana kegiatan dilakukan untuk mencapai tujuan. Jelaskan indikator tercapainya tujuan dan tolak ukur yang digunakan untuk menyatakan keberhasilan dari kegiatan pengabdian yang telah dilakukan. Ungkapkan keunggulan dan kelemahan luaran atau fokus utama kegiatan apabila dilihat kesesuaiannya dengan kondisi masyarakat di lokasi kegiatan. Jelaskan juga tingkat kesulitan pelaksanaan kegiatan maupun produksi barang dan peluang pengembangannya kedepan. Artikel dapat diperkuat dengan dokumentasi yang relevan terkait jasa atau barang sebagai luaran, atau fokus utama kegiatan. Dokumentasi dapat berupa gambar proses penerapan atau pelaksanaan, gambar prototype produk, tabel, grafik, dan sebagainya.

\section{KESIMPULAN}

Pada dasarnya, para pelaku usaha yang tergabung dalam UMKM MANGGAR SARI, telah melakukan pencatatan, namun bentuk pencatatannya tidak kontinyu dan tidak disimpan serta tidak ada format yang baku. Mereka hanya mencatat pada saat belanja bahan misalnya dan tidak dibuat catatan secara formal. Kadang kala juga tidak melakukan pencatatan sama sekali dalam berproduksi dikarenakan sudah terbiasa/hafal. Kondisi tersebut menyebabkan tidak dapatnya diketahui berapa besar laba yang di terima dan berapa besar harga yang sesuai dengan pengeluaran biaya produksinya. Penetapan harga jual hanya berdasarkan harga pasar dan perkiraan saja. Oleh karena itu, tim pengabdian melakukan pelatihan pembukuan sederhana yang berkaitan dengan pencatatan aliran kas masuk dan keluar serta penyusunan laporan keuangan dan laporan biaya produksi sehingga para pelaku usaha bisa menetapkan harga sesuai dengan biaya produksi yang dikeluarkan ditambah dengan margin laba tertentu.

Pemasaran produk dari UMKM MANGGAR SARI masih mengunakan cara tradisional dengan melakukan pemasaran secara langsung ke pembeli dan belum semuanya memanfaatkan teknologi atau menggunakan media sosial. Mereka juga belum mempromosikan produk mereka melalui media. Kondisi itu menyebabkan hanya beberapa konsumen saja yang mengenal produk yang mereka jual. Tim pengabdian memberikan pelatihan baik materi maupun praktek yaitu membuat e-poster untuk mempromosikan produk. Tim juga memberi pelatihan cara memasarkan produk melalui media facebook dan instragram.

\section{UCAPAN TERIMAKASIH}

Kegiatan pengabdian kepada masyarakat dalam bentuk pendampingan pengelolaan keuangan telah berjalan lancar, hal ini tidak terlepas dari bantuan dan dorongan dari berbagai pihak, oleh karena itu dalam kesempatan ini kami menyampaikan ucapan terima kasih kepada: 
1. Dr. Nur Fadjrih Asyik, M.Si., Ak., CA selaku Ketua STIESIA Surabaya yang telah memberikan kesempatan, petunjuk, dan motivasi kepada kami sehingga kami bisa melaksanakan kegiatan ini dengan baik

2. Dr. Nur Laily, M.Si selaku ketua LP2M STIESIA Surabaya, yang telah memberikan kesempatan kepada kami untuk melakukan kegiatan pengabdian masyarakat

3. Seluruh pengurus anggota UMKM Manggarsari Kelurahan Pacar Keling, Kecamatan Tambak Sari yang telah dengan baik dan semangat dalam mengikuti kegitan pendampingan ini sehingga bisa berjalan dengan baik.

Semoga kegiatan ini banyak memberikan manfaat, baik bagi diri kami, bagi institusi (STIESIA Surabaya), dan juga bagi UKM Manggarsari Kelurahan Pacar Keling Kecamatan Tambaksari Surabaya

\section{DAFTAR PUSTAKA}

Ardiana, I., Brahmayanti, I., \& Soebandi. (2010). Kompetensi SDM UKM dan Pengaruhnya Terhadap Kinerja UKM di Surabaya. Jurnal Manajemen Dan Kewirausahaan, 12 (1), 42-55. https://doi.org/10.9744/jmk.12.1.pp.\%2042-55

Dahlan, T., Murfiah, U., \& Indriani, R. (2018). Pelatihan Pembukuan Sederhana bagi UKM Kerajinan Anyam Pandan di Kecamatan Rajapolah, Tasikmalaya. Jurnal SOLMA, 7(2), 153160. https://doi.org/10.29405/solma.v7i2.2109

Dewi. S.T SAK EMKM, Menilik Standar Akuntansi untuk UMKM Rancangan IAI. https://goukm.id/sak-emkm/. Diakses tanggal 4 Mei 2021

Gunaedi, J., Nastiti, H., \& Wijaya, S. Y (2018) UKMK Pembukuan Akuntansi Sederhana. Prosiding Seminar Hasil Pengabdian Kepada Masyarakat ISBN: 978-602-73114-5-9 https://conference.upnvj.ac.id/index.php/pkm/article/view/57

Hadziq, M., \& Nafis, M. (2017). Implikasi Pendampingan Mitra Usaha Kecil Menengah (Studi Pendekatan Melalui Pelatihan Laporan Keuangan Sederhana). Jurnal Middle East and Islamic Studies, 396-409. https://doi.org/10.7454/meis.v4i2.44

Hayati, R. (2019) Pengertian Identifikasi Masalah, Bagian, dan Cara Membuatnya. https://penelitianilmiah.com/identifikasi-masalah/

https://www.trusvation.com/apa-saja-strategi-pemasaran-online-yang-efektif-untuk-umkm/ diakses tanggal 4 Mei 2021

Nugroho, L., Hidayah, N., Ali, A., \& Badawi, A. (2020). E-Commerce to Improve Homemaker Productivity (Women Entrepreneur Empowerment at Meruya Utara, Kembangan District, West Jakarta, Indonesia). Amalee: Indonesian Journal of Community Research and Engagement, 1(1), 13-24. https://doi.org/10.37680/amalee.v1i01.166

Marka, M. M., Aziz, N., \& Alifiana, M. A. (2018). Pengembangan UMKM Madumongso Melalui Manajemen Usaha Dan Legalitas Usaha. ABDIMASLP2M Universitas Negeri Semarang https://journal.unnes.ac.id/nju/index.php/abdimas/article/view/16512

Sari, C.T \& Indriyani, E. (2017). Pentingnya Pembukuan Sederhana Bagi Kelompok UMKM KUB Murakabi Desa Ngaryoso. Jurnal Pengabdian Pada Masyarakat Wasana Nyata Vol 1 No 1 https://e-journal.stie-aub.ac.id/index.php/wasana_nyata/article/view/189/182

Sudaryanto, Ragimun, \& Wijayanti, R. R. (2014). Strategi Pemberdayaan UMKM Menghadapi Pasar Bebas Asean. Www.Kemenkeu.Go.Id, http://www.perpustakaan.depkeu.go.id 
Wahyuningsih, E.D., Setiawati, I., \& Prasojo, T. A., (2017). Pemberdayaan Pelaku Usaha Mikro Dengan Memberikan Pelatihan Pembukuan Sederhana Di Desa Bangunrejo Kecamatan Patebon Kabupaten Kendal. Prosiding Seminar Nasional \& Internasional. Unmuh Semarang. http://www.ejurnal.stiedharmaputra-smg.ac.id/index.php/PRO/article/view/263

Widhiasturi, R., Kardiyem., \& Farliana, N. (2019). Model Akuntansi Sederhana Bagi UMKM Makanan Kota Semarang. Jurnal Pengabdian dan Pemberdayaan Masyarakat Vol. 3 No.1 DOI: $\underline{10.30595 / \mathrm{jppm} . v 3 i 1.4043}$ 